RESEARCH LETTER

Volume 2 (2021), No. 1, pp. 23-28

DOI: $10.15367 /$ ch.v2i1.406

\title{
Evaluating the Parenting of Caregiving Grandparents
}

\author{
SYLVIA FORMAN 1 \\ ${ }^{1}$ Supportive Older Women's Network
}

Correspondence: sylvia.forman@temple.edu (Sylvia Forman)

\begin{abstract}
Background and Purpose: In Pbiladelphia, approximately 14,000 grandparents are caring for over 16,000 grandchildren. The SOWN GrandFamily Resource Center (GFRC) provides social services and parenting education for low-income, caregiving grandparents in the Philadelphia area. This project investigates whether grandmothers participating in the GFRC report changes in parenting on the annual Department of Human Services (DHS) Parenting Collaborative pre- and post-survey. Methods: Selected survey questions from the DHS Parenting Collaborative survey were grouped into subscales measuring social support and positive parenting practices. Associations between social support and parenting were examined using Pearson's correlation coefficient, and average subscale scores and percentage of grandparents demonstrating positive parenting practices were compared between 16 matched pre- and post-surveys using paired t-tests and McNemar's tests, respectively. Results: McNemar's tests determined that changes in the proportion of grandmothers demonstrating positive parenting for each practice from pre- to post-survey were not statistically significant, with p-values between .625 and 1. The change in mean score for nurturing behavior from pre- to post-survey was statistically significant, t(15) $=-2.21, p=.04$. Social support had a moderate, statistically significant, positive association with all parenting measures. Conclusion: Participants averaged 3.7 years of GFRC participation at the time of the pre-survey and demonstrated high levels of initial knowledge and parenting practice, but not a significant change from pre to post. The positive association between social support and parenting practice is supported by research that a caregiver's distress negatively impacts parenting. Social relevance: Large numbers of grandparents are raising their grandchildren. Understanding the needs of grandparent-headed families and effective ways to provide support is important for the wellbeing of the grandparents and grandchildren involved.
\end{abstract}

Keywords: grandfamilies, parenting, custodial grandparents, caregiving grandparents

\section{Introduction}

In 2019, over 14,000 grandparents in Philadelphia were serving as the primary caregiver for over 16,000 grandchildren, with $40 \%$ of the children having neither parent present. ${ }^{1}$ Nationally, approximately 2.3 million grandparents were serving as the primary caregiver (caregiving grandparent) for 2.7 million grandchildren in 2019.1 Grandparents caring for grandchildren are more likely to experience depression and anxiety and tend to have higher levels of stress than their non-caregiving peers. ${ }^{2}$

The SOWN GrandFamily Resource Center (GFRC) provides weekly, hour-long, professionally facilitated support groups for primarily low-income, caregiving grandparents in the Philadelphia area. Support groups are on-going, and caregiving grandparents are eligible as long as they live with and are the primary 
caregiver for one or more grandchild. While the majority of participants are caregiving grandmothers, GFRC programs have expanded to include grandfathers caring for their grandchildren as well. Both telephone groups and in-person groups at community and health centers are available. Individual counseling is also provided on an as-needed basis, as well as referrals for other services. The support groups are designed to empower participants to help themselves and each other. Parenting education is a central topic of the GFRC program. The purpose of this project was to determine whether grandmothers participating in the GFRC report parenting changes as a result of the GFRC program using the written, self-report Department of Human Services (DHS) Parenting Collaborative pre-survey (administered every September) and post-survey (administered in June).

\section{Methods}

Out of 21 grandmothers who completed the pre-survey between 2015 and 2018, 16 completed the postsurvey and were included in this study. Participants attended an average of 2.5 GFRC group sessions per month. See Table 1 for participant demographic information.

Table 1. Demographic Description of Grandmother Caregivers

\begin{tabular}{|c|c|c|c|c|}
\hline Characteristic & Mean & $(\mathrm{SD})$ & Count & $\%$ \\
\hline $\begin{array}{l}\operatorname{Age}(\mathrm{n}=16) \\
\operatorname{Min}: 51.1 \\
\operatorname{Max}: 82.1\end{array}$ & 65.8 & $(8.6)$ & & \\
\hline Years in service at SOWN $(n=16)$ & 3.7 & $(3.5)$ & & \\
\hline $\begin{array}{l}\text { Number of grandchildren }(\mathrm{n}=16) \\
1 \text { grandchild } \\
2 \text { grandchildren } \\
3 \text { grandchildren }\end{array}$ & 1.6 & $(0.6)$ & $\begin{array}{l}8 \\
7 \\
1\end{array}$ & $\begin{array}{c}50 \% \\
44 \% \\
6 \%\end{array}$ \\
\hline $\begin{array}{c}\text { Race/Ethnicity }(\mathrm{n}=16) \\
\text { African American Black }\end{array}$ & & & 16 & $100 \%$ \\
\hline $\begin{array}{l}\text { Marital Status }(\mathrm{n}=16) \\
\text { Single } \\
\text { Married } \\
\text { Widowed }\end{array}$ & & & $\begin{array}{c}12 \\
3 \\
1\end{array}$ & $\begin{array}{c}75 \% \\
19 \% \\
6 \%\end{array}$ \\
\hline $\begin{array}{l}\text { Education }(\mathrm{n}=16) \\
\text { High school } \\
\text { Post high school/some college } \\
\text { College and/or graduate school }\end{array}$ & & & $\begin{array}{c}11 \\
1 \\
4\end{array}$ & $\begin{array}{c}69 \% \\
6 \% \\
25 \%\end{array}$ \\
\hline
\end{tabular}

Selected questions from the 46-item DHS Parenting Collaborative survey were grouped into subscales measuring social support and parenting practices around nurturance, discipline, and communication. The parenting practices and specific questions were selected in collaboration with the GFRC coordinator and the SOWN Director of Programs to be the most relevant to the focus of GFRC parenting education. The subscales have not been validated. See Table 2 for a more detailed description of the subscales and questions. 
Table 2. Description of Parenting Behavior Subscales

\begin{tabular}{|c|c|c|}
\hline Subscale & Description & Subscale Description \\
\hline Discipline & $\begin{array}{l}\text { Use of positive discipline } \\
\text { techniques (e.g., discipline based } \\
\text { on learning for the future rather } \\
\text { than punishment for the past) }\end{array}$ & $\begin{array}{l}\text { Subscale: } 2 \text { questions } \\
\text { Sample question: } \\
\text { I praise my child when he/she } \\
\text { behaves well. }\end{array}$ \\
\hline Nurturance & $\begin{array}{l}\text { Quality of caregiver-child } \\
\text { relationship: positive } \\
\text { atmosphere, acceptance, } \\
\text { emotional support, playing with } \\
\text { or reading to child }{ }^{4} \text { (see note) }\end{array}$ & $\begin{array}{l}\text { Subscale: } 4 \text { questions } \\
\text { Sample question: } \\
\text { I spend time with my child doing } \\
\text { what he/she likes to do. }\end{array}$ \\
\hline Communication & $\begin{array}{l}\text { Listening to each other and } \\
\text { talking things through }\end{array}$ & $\begin{array}{l}\text { Subscale: } 3 \text { questions } \\
\text { Sample question: } \\
\text { When we argue, my family listens } \\
\text { to "both sides of the story". }\end{array}$ \\
\hline Social Support & $\begin{array}{l}\text { Having someone available to } \\
\text { talk to }\end{array}$ & $\begin{array}{l}\text { Subscale: } 3 \text { questions } \\
\text { Sample question: } \\
\text { I have others who will listen when } \\
\text { I need to talk about my problems. }\end{array}$ \\
\hline
\end{tabular}

Note: Smith GC, Hayslip B, Hancock GR, Strieder FH, Montoro-Rodriguez J. A randomized clinical trial of interventions for improving well-being in custodial grandfamilies. J Fam

Psychol. 2018 Sep 1;32(6):816-27.

Question responses were Strongly Disagree (1) to Strongly Agree (4) (no Neutral). Questions were reverse scored as necessary so that answers corresponding to 3 or 4 indicated a positive response. Subscale scores were computed by averaging the responses to the questions included in the subscale (after reverse scoring) and ranged from 1 to 4 . Higher scores on each subscale indicate a more positive outcome. Scores of 3 and above on parenting scales were considered to indicate positive parenting practice. The mean scores for all participants for each subscale were compared between pre- and post-surveys using paired t-tests. The proportion of grandmothers demonstrating positive parenting practice for each scale from pre- to post-survey was compared using a McNemar's test. The correlations between the mean scores for social support and each parenting subscale were also examined using Pearson's correlation coefficient.

\section{Results}

The results include 16 grandmothers completing pre-and post-surveys. Respondents indicated a high level of positive parenting on the pre-survey. Each parenting subscale had a mean score of at least 3 with at least $75 \%$ of grandmothers demonstrating positive parenting (scoring a 3 or higher). The increase in the mean score for nurturance from pre- to post-survey was statistically significant $(p=.04)$. The results for each subscale are shown in Table 3. 
Table 3. Comparison of Parenting Behaviors from Pre- to Post-Survey

\begin{tabular}{|c|c|c|c|c|c|c|}
\hline \multirow[b]{2}{*}{$\begin{array}{l}\text { Parenting } \\
\text { Behavior }\end{array}$} & \multicolumn{2}{|c|}{ Pre-Survey } & \multicolumn{2}{|c|}{ Post-Survey } & \multirow{2}{*}{$\begin{array}{l}\text { Paired t-tests } \\
\text { comparing } \\
\text { means }\end{array}$} & \multirow{2}{*}{$\begin{array}{c}\text { McNemar's } \\
\text { Tests for } \\
\text { proportions }\end{array}$} \\
\hline & Mean & $\begin{array}{c}\% \text { with } \\
\text { score } \geq 3\end{array}$ & Mean & $\begin{array}{c}\% \text { with } \\
\text { score } \geq 3\end{array}$ & & \\
\hline $\begin{array}{l}\text { Nurturance } \\
(\mathrm{n}=16)\end{array}$ & 3.17 & $75 \%$ & 3.39 & $100 \%$ & $\begin{array}{c}t(15)=-2.21 \\
p=.04^{*}\end{array}$ & $p=.13$ \\
\hline $\begin{array}{l}\text { Discipline } \\
(n=16)\end{array}$ & 3.56 & $93.8 \%$ & 3.28 & $81.3 \%$ & $\begin{array}{c}t(15)=1.71 \\
\quad p=.11\end{array}$ & $p=.50$ \\
\hline $\begin{array}{l}\text { Communication } \\
(\mathrm{n}=15)\end{array}$ & 3.17 & $87.5 \%$ & 3.24 & $93.3 \%$ & $\begin{array}{c}t(14)=-0.68 \\
p=.51\end{array}$ & $p=1.0$ \\
\hline
\end{tabular}

According to McNemar's tests, the changes in the proportion of grandmothers with positive parenting practices were not statistically significant; however, it is notable that the proportion showing nurturing behavior increased from $75 \%$ on the pre-survey to $100 \%$ on the post-survey (Table 3). Social support had a moderate, positive association with all three parenting measures, meaning that higher levels of social support were associated with higher levels of positive parenting. The association was statistically significant at the $p<.05$ level for all three parenting measures (Table 4).

Table 4. Pearson's Correlation Coefficient (r) Between Social Support and Parenting Behaviors

\begin{tabular}{cccc}
\hline & $\begin{array}{c}\text { Nurturance } \\
(\mathrm{n}=16)\end{array}$ & $\begin{array}{c}\text { Discipline } \\
(\mathrm{n}=16)\end{array}$ & $\begin{array}{c}\text { Communication } \\
(\mathrm{n}=15)\end{array}$ \\
\hline Social Support & $\begin{array}{c}r(14)=.69 \\
p=.003\end{array}$ & $\begin{array}{c}r(14)=.53 \\
p=.030\end{array}$ & $\begin{array}{c}r(13)=.54 \\
p=.036\end{array}$ \\
\hline
\end{tabular}

\section{Conclusion and Social Relevance}

One possible explanation for the increase in nurturance is that a caregiver's own distress may interfere with offering emotional support. Improving parenting practices such as discipline could lead to a less stressful relationship, enabling caregivers to provide more emotional support. The positive association between social support and parenting practice is supported by research that a caregiver's distress has a negative impact on parenting ${ }^{3}$ as more social support is likely to reduce distress. Addressing distress by increasing social support may also by itself have a positive impact on parenting. SOWN's focus on social support and parenting education is a promising combination for improving parenting among caregiving grandparents.

Participants demonstrated high levels of parenting practice on the pre-survey. One reason for this could be that participants averaged 3.7 years of GFRC participation at the time of the pre-survey, so the presurvey was not a true pre-test. This makes it difficult to measure the impact of the GFRC program, but high scores on the pre-survey could be due to program participation. Because parenting education is a

CommonHealth $26 \quad$ April 2021 | Volume XX | Issue XX


focus of the GFRC program, the fact that the grandmothers included in this study stayed in the program for an extended time implies that the program is relevant and beneficial to participating caregiving grandmothers.

In order to further study parenting changes due to the GFRC program, a control group of caregiving grandparents not participating in the GFRC who take the same pre- and post-survey would be beneficial. In addition, administering the pre-survey to participants when they enroll in the GFRC instead of at a set time of year would provide more accurate pre-test results. Finally, the number of participants included in this study was small and homogeneous which does not allow generalization to all grandparent caregivers. More research is needed to determine the most effective way to promote positive parenting practices among caregiving grandparents.

Large numbers of grandparents are raising their grandchildren, often without a parent involved. Understanding the needs of these grandparent-headed families and evaluating programs to ensure they are effective is important for the wellbeing of the grandparents and grandchildren involved.

\section{Disclosures and Conflicts of Interest}

There are no conflicts of interest to report. These data were previously reported in poster sessions at the College of Physicians Poster Presentation, February 15 ${ }^{\text {th }}$, 2019, and the Temple University College of Public Health Research Day, April 5th, 2019.

\section{Acknowledgments}

Thanks to Arlene Segal (SOWN GFRC), Merle Drake, Marypat Tracy, Bettina Pearl, and Beth Varcoe (SOWN), Adele Struble (DHS Parenting Collaborative) and Anne Frankel (Temple University) for their help with this project. 


\section{References}

1. US Census Bureau. (No Title) [Internet]. 2019 [cited 2021 Feb 10]. Available from: https://data.census.gov/cedsci/table?q=grandparent caregivers\&tid $=$ ACSDT1Y2019.B10002 $\&$ tp $=$ true $\&$ hidePreview $=$ true

2. Pilkauskas N V, Dunifon RE. Understanding grandfamilies: Characteristics of grandparents, nonresident parents, and children. J Marriage Fam. 2016;78(3):623-33.

3. Smith GC, Palmieri PA, Hancock GR, Richardson RA. Custodial grandmothers' psychological distress, dysfunctional parenting, and grandchildren's adjustment. Int J Aging Hum Dev. 2008;67(4):327-57.

4. Smith GC, Hayslip B, Hancock GR, Strieder FH, Montoro-Rodriguez J. A randomized clinical trial of interventions for improving well-being in custodial grandfamilies. J Fam Psychol. 2018 Sep $1 ; 32(6): 816-27$.

\section{About the Author(s)}

Sylvia Forman earned a PhD in Mathematics from the University of Iowa in 1999, and taught college mathematics for several years, including at Saint Joseph's University. In December 2019, she earned an MPH from Temple University, specializing in Social and Behavioral Sciences. She is interested in evaluation and currently, she is working at SOWN as the Evaluation Coordinator.

\section{ORCID IDs}

Sylvia Forman: https://orcid.org/0000-0003-2204-6002 